\title{
多水質項目の物理現象モデルに基づく 水道の高度処理システムの最適設計
}

\author{
早貸外幸 ${ }^{1} \cdot$ 真柄泰基 $^{2} \cdot$ 大井紘 $^{3} \cdot$ 橋本伊織 ${ }^{4}$ \\ ${ }^{1}$ 正会員 工修（株）日水コン 技術推進部長 水道本部（†163-11 東京都新宿区西新宿 6-22-1） \\ 2 正会員 工博 国立公衆衛生院 部長 水道工学部 ( 108 東京都港区白金台 4-6-1) \\ ${ }^{3}$ 正会員 工博 国立環境研究所 上席研究官 社会環境システム部（テ305 つくば市小野川 16-2） \\ 4 工博 京都大学 教授 工学部 (
}

\begin{abstract}
水道の净水水質を安定的に確保するため, オゾン処理等から構成される高度処理に原水調整池及び浄水池を有 する水質安定システムについて, トリハロメタン生成能など三水質項目の制約条件を満足し, 浄水処理費用を最 小ならしめる最適設計を求めた。 その設計方程式は物質収支に基づく物理現象モデルについて設定し，その反応 速度定数をアレニウスの式とした。この水質安定システムの最適設計問題を淀川下流の原水水質に適用し, 最適 化計算はコンプレックス法により解き, 最適設計問題の妥当性と現実性を検証し, システムの特性も明らかにし た.
\end{abstract}

Key Words : trihalomethane, advanced treatment, Arrhenius' equation, buffer reservoir, material balance, cost optimization, system characterlistics

\section{1.はじめに}

水道水源の污濁が進み, 水道水においては異臭味被害 が毎年大略 1500 万人にも及び, 加えて農薬やトリハロ メタンも検出される状況となり，水道水質の安全性に対 する不安や不信感が，国民の間に広がっている．このた め, 1992 年 12 月に厚生省は，水道法の水質基準を約 35 年ぶりに改訂した。これを達成するための根本的な対策 は, 水道水源の水質保全であるとして, 政府は水道水源 水質保全のための法律を 1994 年 2 月に制定した。一方, 1994 年版の環境白書によると, 水道水源とされている 河川に係わる環境基準の達成率は依然として $75 \%$ 程度 に留まり, 完全な達成にはなお時間を要するものと憂慮 される.このように, 水質基準を確保するための根本的 な対策である水道水源の水質保全対策は緒に就いたばか りである，そのため，水質污濁が進んでいる河川を水源 亡する場合は, 净水処理費用の增大を伴うものの, 净水 の水質保全を図るために水道事業における方策の一つと して, 高度処理の導入を積極的に取り入れる事例が増加 しつつある1) その効果もあって厚生省の調査によると, 1994 年の異臭味による被害者数は, わずかではあるが 低減の兆しが見えつつある.

このような状況を踏まえ，本報では，高度処理の導入 に当たり浄水処理費用を最小にするという意味で, 合理 的な設計を行うための最適設計問題を取り上げる．その
ため, 在来型の沈殿と濾過から構成される通常処理に, 生物処理, オン゙ン処理, 及び生物活性炭処理を付加した 净水処理システムをサブシステムとし，これと原水調整 池や净水場に設置されている净水池加ら構成されるシス テムのモデルを設定した．このシステムにおいて考慮の 対象とする水質項目は, 異臭味や安全性之関連が深いア ンモニア性窒素, トリハロメタン生成能, 及びジメチル イソボルネオールの 3 項目である. この三水質項目につ いて各処理施設ごとに, システムモデルの構成に必要な 設計方程式は, 物質収支に基づく物理的な現象モデルに ついて設定した．河川水質（三水質項目に水温を含む） に季節変動があることから,水温の影響を反映するため, この設計方程式に含まれる反応速度定数をアレニウスの 式とし, そのパラメータは淀川下流に設置された実証プ ラントから得られたデー夕を適用して決定した。これら の設計方程式を用いてシステムモデルを構成し，費用関 数式を用いて净水処理費用を最小にするという観点から 目的関数を定めて, 最適設計問題を定式化した.

この最適設計問題の妥当性と現実性を検証するため に, これを実際に数値計算によって解いた. 最適化計算 の方法は, 非線形の極值問題に適用されるコンプレック ス法 (非線形の極值問題に対するシンプレックス法を不 等号制約条件つき問題に拡張したもの) を用いた。 その 結果, 三水質項目の水道法における水質基準などを送水 における目標値としてそれを達成し, かつ総費用（建設 


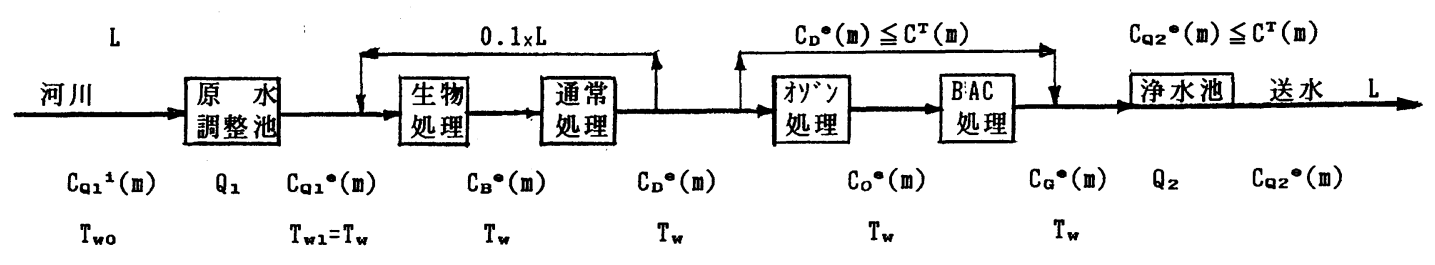

図一1 水質安定システムの構成

費と運転費との和）を最小ならしめる最適設計が求めら れた。 さらに，原水調整池や浄水池の容量には，それら に水質の時間的な変動幅を平準化する効果があるので, 送水における目標值のレベルによっては，オゾン処理を 不要とするシステム特性を有することも判明した.

この種の試みは筆者らが行った前報 ${ }^{2), 31}$ 以外に少ない. それらに比べた本報の独自性は以下のとおりである.

(1) 高度処理にオゾン処理も含めたこと.

(2) 原水調整池亡净水池の双方を同時に最適設計の対 象に含めたこと.

(3) 状態変数は過マンガン酸カリウム消費量のみでな く前述の三水質項目に着目したこと.

(4) 設計方程式の設定方法は回帰式による統計的手法 ではなく, 水温の季節変動の影響を考慮し, 反応 速度定数にアレニウスの式を適用した物質収支に よる物理的な現象モデルを用いて，現象をより忠 実にかつ精度良く反映するものとしたこと．

(5) 本報におけるシステムモデルの定式化は, 必要に 応じ多成分系への展開が可能であること.

(6) 不等号制約条件付き，非線形最適化問題として定 式化し，その具体的な解法を与えたこと.

\section{2. システムモデルの設定}

水道水源の污濁から生じる異臭味水の発生や安全性の 問題が, 水道にとって大きな課題となっているため, こ れらの状況に的確に対応できるシステムモデルが必要で ある. したがって, 高度処理を含む净水処理システムに 原水調整池や净水池の容量による平準化も考慮すると, 送水における目標值（以下，「目標水質」という.）をよ り一層確実に達成し易くなることから, システムモデル は図一1に示す構成要素加なるもの（以下，「水質安 定システム」という.）とする. 河川から取水された水 量 $L$ で, 処理対象であるアンモニア性窒素, トリハロ メタン生成能, 及びジメチルイソボルネオール（以下, 「着目成分」と呼び，それぞれ「 $\left.\mathrm{NH}_{4}-\mathrm{N}\right\rfloor$ 「THM-FP」, $\left\lceil 2\right.$-MIB」と表す. ) の濃度 $C_{Q 1}{ }^{i}(m)$, 水温 $T_{w 0}$ （絶対温 度）の原水は, 原水調整池 $Q_{1}$ に導入される. その容量 により，第 3 章 5 節 a ) で述べる流量と水質の両方を考 慮する完全混合モデルに基づき変動する水量 $L$ の水質
の時間変動幅が平準化 (以下,「平準化」という.) され て $C_{Q 1}{ }^{e}(m), T_{w 1}\left(=T_{w}\right)$ となるが, 生物処理施設以降の 水温は一定 $T_{w}$ とする. 次に, 生物処理施設, 通常処理 施設の順で処理され, さらに, オゾン処理施設, 生物活 性炭（粒状活性炭の表面に微生物が付着した状態で, 以 下, 「BAC」という. ) 処理施設を経て净水池へ送られる. その後, 浄水池においてはその容量により, 水質が平準 化されて $C_{Q 2}{ }^{e}(m)$ となる.

最適化の計算は，第 4 章 1 節で述べるとおり半旬（ 5 日間) 単位で行っているが, 水量 $L(t\}$, 施設 $j$ におけ る任意の着目成分 $m$ の濃度 $C_{j}(m, t)$ などは, 記述が幅 軼するため, 便宜上第 3 章の 4 節まで時間 $t$ を省略し, $L, C_{j}(m)$ と表記する. また, 水質安定システムの構成 要素は, 第 3 章で詳述する各施設 $j$ であり, それぞれの 記号は原水調整池を $Q_{1}$, 生物処理施設を $B$, 通常処理 施設を $D$, オゾン処理施設を $O, B A C$ 施設を $G$, 及び 净水池を $Q_{2}$ と記す. 当該システムの状態変数は, 着目 成分である三水質項目の濃度であり $\mathrm{NH}_{4}-\mathrm{N}, \mathrm{THM}-\mathrm{FP}$, 及び 2-MIBをそれぞれ $C(N), C(H)$, 及び $C(M)$ と記す. したがって, 状態変数 $\left\{C_{j}{ }^{i}(N), C_{j}{ }^{i}(H), C_{j}{ }^{i}\right.$ $(M)\}$ を持つ処理水量 $L$ の施設 $j$ への流入水 (以下, 「被 処理水」という. ) は, 施設 $j$ において水質 $\left\{C_{j}{ }^{e}(N)\right.$, $\left.C_{j}{ }^{e}(H), C_{j}{ }^{e}(M)\right\}$ を有する施設 $j$ 加らの流出水（処理 施設内の流動状況が完全混合の場合の処理施設内の水も 含め, 以下, 「処理水」という.）に処理される. $C^{T}(m)$ は着目成分 $m$ の目標水質を示し, $Q_{1}$, と $Q_{2}$ は各々の容 量により平準化の効果を有する原水調整池と浄水池の容 量をも表わす.

なお，取水から送水までは自然流下を仮定する．また， 通常処理の洗浄排水などは着水井へ戻され, そのため生 物処理亡通常処理の処理水量は $10 \%$ 増加するが, 水質 への影響は無く, 返送ポンプの費用も考慮しないものと する. 通常処理後の三水質項目の濃度が全て目標水質を 達成している場合は, オゾン処理, 及び $B A C$ をバイパ スさせる.

\section{3. 設計方程式及び費用関数式}

净水処理費用を最小化ならしめるように水質安定シス テムの最適設計を行うには, 設計変数を独立変数とし各 


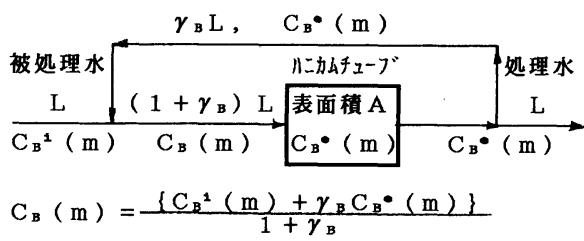

図一2 生物処理

処理施設の入口と出口における状態変数を従属変数とす る設計方程式並びに各施設の建設費と運転費からなる当 該システムの費用関数式を設定する必要がある.

本章各節で後述のとおり, 各処理施設の設計変数は八 ニカムチューブの表面積, オゾン注入率, 及び $B A C$ の 空塔接触時間であり，それらを順に $\{A, \eta, \tau\}$ 之記す。 また，通常処理施設は水質安定システムに含まれるが, 第 2 節で述べる理由により最適化の対象としないので設 計変数は存在しない.

水質安定システムの設計方程式は, 図一1の各処理施 設と状態変数ごとに, 以下に述べる方法により, 物質収 支から設定する，その際，設計方程式において，河川水 温の季節変動による影響をより忠実に反映するため, 反 応速度定数はアレニウスの式とする.そのパラメータは, 淀川下流の河川水を原水とする実証プラントから得られ たデータに基づき決定する．ただし，ここでの設計方程 式とそのパラメータは, 計画段階における水質安定シス テムの総費用を最小化ならしめる最適設計を目的とする もので, 水質安定システムを構成する各施設について個 別の設計などに当たり，一般的にそのまま利用すること を意図したものではない.

以下，施設ごとに設計方程式を順次示す.

\section{（1）生物処理施設}

実証プラントは図一2 に示すとおり, 表面積 $A$ のハニ カムチューブが充填されている. 水質の季節変動に応じ たプラントの挙動を表わす測定データは，プラントの入 口 $C_{B}{ }^{i}(m)$ と出口 $C_{B}{ }^{e}(m)$ について得られている. 処 理水はその一部がリサイクル率 $\gamma_{B}$ により施設の入口へ 戻されるので, 入口直前の濃度は $C_{B}(m)$ となる. また, ばっ気により十分摚拌されているので，その流動状況は 完全混合亡見なす ${ }^{4), 5}$. 反応の場がハニカムチューブ表 面に限定されているので, 反応速度はその単位表面積当 りと( ${ }^{6)}$, 反応次数を 1 次とする ${ }^{7,8)}$. 状態変数の入口濃 度 $C_{B}{ }^{i}(m)$, 出口濃度 $C_{B}{ }^{e}(m)$ について物質収支をとる 之, 式（1）と（2）で表わされる.

なお, 反応速度式は反応速度定数を $K_{B}(m)$, 原水の 水温（処理に伴う温度変化を無視し，その他の施設にお いても同じ.）を $T_{w}$ としてアレニウスの式とする. 反
応速度定数のパラメータは, 頻度因子, 活性化エネルギ, 及び気体定数であり，それぞれ $K_{B 0}(m), E_{B}(m)$, 及 び $R$ と記す.

$$
\begin{aligned}
& L \cdot\left[C_{B}{ }^{i}(m)-C_{B}{ }^{e}(m)\right]=K_{B}(m) \cdot C_{B}{ }^{e}(m) \cdot A \\
& \text { ただし }, K_{B}(m)=K_{B 0}(m) \cdot \exp \left(\frac{-E_{B}(m)}{R \cdot T_{w}}\right)
\end{aligned}
$$

$K_{B 0}(m), E_{B}(m)$ は実証プラントのデータを用いて, 次のとおり状態変数ごとに決定する. 式 $(1)$ に式 (2) を代入し，その両辺の対数をとると，式 $(3)$ を得る. 実測デー夕 $L, C_{B}{ }^{i}(m), C_{B}{ }^{e}(m), T_{w}$ を式 (3) に適 用し，アレニウスプロットを利用して，横軸に $1 / T_{w}$ を, 縦軸に式（3）の左辺の値をとって直線回帰により，切 片から $K_{B 0}(m)$ を，勾配から $E_{B}(m) / R$ をそれぞれ求 める.

$$
\begin{aligned}
\ln L & +\ln \left[C_{B}{ }^{i}(m)-C_{B}{ }^{e}(m)\right]-\ln C_{B}{ }^{e}(m)-\ln A \\
& =\ln K_{B 0}(m)-\left(\frac{E_{B}(m)}{R}\right) \cdot\left(\frac{1}{T_{w}}\right)
\end{aligned}
$$

\section{（2）通常処理施設}

通常処理施設の設計方程式は, 処理プロセスのメカニ ズムにまで立ち入らず，水質の季節変動に配慮しながら 実プラントの実績デー夕に基づき, 入口濃度 $C_{D}{ }^{i}(m)$ 之出口濃度 $C_{D}{ }^{e}(m)$ との関係を回帰式加ら求める統計 的方法により設定した. その理由は, 次のとおりである.

(1) 通常処理は主に懸濁物質を処理対象として，永年 の間利用され成熟した技術である。

(2) 高度処理の付加により補完する必要があることか らも伺えるように，それ単独では微量化学物質な ビを十分に処理するためのものではない.

したがって，設計方程式は水質の実績データの季節的 な分布とバランスに配慮しながら $C_{D}{ }^{i}(m)$ と $C_{D}{ }^{e}(m)$ 亡の関係から設定する. 4 タイプ (直線, 対数, 指数, べき乗) の回帰式のうちから決定係数が一番大きい夕イ プを選定する方法により，設計方程式は式（4）のとお りべき乗タイプを設定した. 回帰式の係数は記述の便宜 上，他の処理施設と同様に $K_{D 0}(m), E_{D}(m) / R$ と表記 する.

$$
C_{D}{ }^{e}(m)=K_{D 0}(m) \cdot\left[C_{D}{ }^{i}(m)\right]^{E_{D}(m) / R}
$$

\section{（）オゾン処理施設}

水質デー夕を得た実証プラントの施設は，オゾン吸収 槽と反応槽から構成されているが, これらを一つの槽と 見なして接触槽之呼ぶ. 施設の入口と出口で得られた実 測データに基づき，接触槽の数式モデルを同定する.

オゾン化空気は主として吸収槽で被処理水に吸収され る. 吸収された溶存オゾンは自己分解も伴いながら ${ }^{9)}$, 着目成分及びその他の全ての被酸化物質と反応する. 


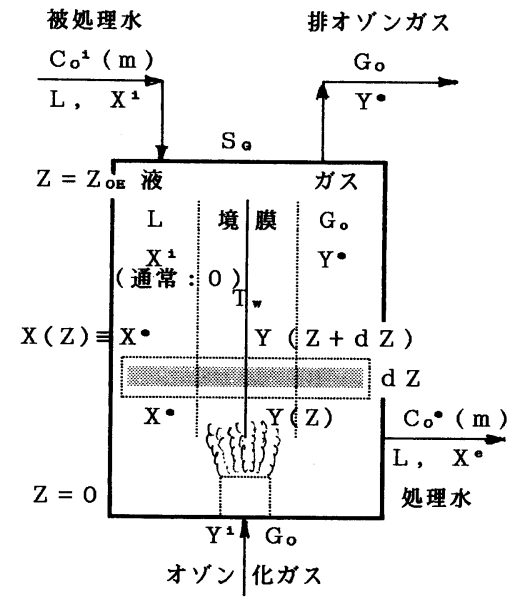

図一3 ガス栓流・液完全混合モデル

\section{a）ガス栓流・液完全混合モデル}

図一3に, オゾン処理接触槽のガス栓流・液完全混合 モデルの模式図を示す.オゾン化空気は接触槽の底部か ら, 一方, 被処理水は接触槽の頂部から, それぞれ一定 流量が定常状態で向流により接触槽へ流入する. 接触槽 におけるオゾン化空気と処理水それぞれの流動状況は才 ゾン化空気が栓流, 処理水が完全混合で, 槽内の水温は 一様であると仮定する10) 13).

\section{b）オゾン移動速度式}

二重境膜説に基づき，オゾン化空気はガス本体からガ ス側境膜を通り, 液側境膜を経由して液本体へ移動し吸 収されるとする ${ }^{10)}$. 液の境膜におけるオゾンの拡散係数 を $D_{o}$, 境膜厚さを $\delta$, 総括物質移動係数を $K_{L}$ とする. さらに, 槽内の溶存オゾン濃度を $X$, 気・液界面にお けるオゾン平衡濃度をそれぞれ $Y^{*}, X^{*}$ とし, 槽内の 水深 $Z$ におけるガス்中オゾン濃度を $Y(Z)$ とする. オ ゾンが二重境膜を経由してガス側から液側へ移動する単 位面積当たりの移動速度 $F$ は, 気相における拡散速度 が液相より格段に速く気相の境膜が無視でき, $Y(Z)=$ $Y^{*}$ であるので, 次の関係で表わされる10),11),14).

$$
\begin{aligned}
F & =\left(D_{o} / \delta\right) \cdot \beta_{o} \cdot\left(X^{*}-X\right) \\
& =K_{L} \cdot \beta_{o} \cdot\left[\alpha_{o} \cdot Y(Z)-X\right]
\end{aligned}
$$

ただし, $X^{*}=\alpha_{o} \cdot Y(Z)$ において $\alpha_{o}$ は, 水温に依存 する分配係数である ${ }^{15)}$. オゾンの反応速度定数等に依存 する定数 $\beta_{o}$ は, 通常の净水処理において 1 とされるの で10),11),14), 結局, 移動速度 $F$ は次式で表わされる.

$$
F=K_{L} \cdot\left[\alpha_{o} \cdot Y(Z)-X\right]
$$

\section{c) 設計方程式の導出}

ガス相においてガスと液混合相の界面積を $a$, 接触槽 の断面積を $S_{o}$ として物質収支をとると, ガス本体 $G_{o}$ から境膜部分へ移行する量の関係は, 次式で与えられる.

$$
G_{o} \cdot Y(Z)-G_{o} \cdot Y(Z+d Z)-F \cdot a \cdot S_{o} \cdot d Z=0
$$

この式の $F$ に式 $(5)$ を代入して次式を得る.

$$
G_{o} \cdot \frac{d Y(Z)}{d Z}+K_{L} \cdot a \cdot\left[\alpha_{o} \cdot Y(Z)-X\right] \cdot S_{o}=0
$$

$p=\left(K_{L} \cdot a\right) \cdot \alpha_{o} \cdot\left(S_{o} / G_{o}\right), q=1-\exp \left(-p \cdot Z_{o E}\right)$ とおき, 式（6）を境界条件 $Z=Z_{o E}$ で $X=X^{e}, Y(Z)=Y^{e}$, ま た, $Z=0$ で $X=X^{e}, Y(Z)=Y^{i}$ により解くと, 次式を 得る.

$$
Y^{e}=Y^{i} \cdot \exp \left(-p \cdot Z_{o E}\right)+\left(1 / \alpha_{o}\right) \cdot\left(q \cdot X^{e}\right)
$$

次に, 液相において気泡容積率を $h$ とすると, その 値は 1 に比べ十分小さいので, 接触槽での物質収支にお いて $\left(S_{o} \cdot Z_{o}\right) \cdot(1-h) \fallingdotseq\left(S_{o} \cdot Z_{o}\right)$ と見なしても実用的に は差支えない ${ }^{13)}$. 溶存オゾンは自己分解のほか, 着目成 分である三水質項目及びそれに比べ相対的に濃度が高い 着目成分以外の全ての被酸化物質との反応により減少す るので, 着目成分並びにオゾンに関する物質収支は, 以 下のとおりである.

着目成分については, 液が中性付近であれば溶存物質 とオゾンとの反応は擬 1 次反応として差支えな $\left({ }^{10), 11), 13), 16)}\right.$. 反応速度定数はアレニウスの式とし, そ のパラメータを $K_{o}(m)$ とおき, $C_{o}(m)$ に関する物質収 支をとると次式を得る.

$$
\begin{gathered}
L \cdot C_{o}{ }^{i}(m)-L \cdot C_{o}{ }^{i}(m) \\
-K_{o}(m) \cdot C_{o}{ }^{e}(m) \cdot X^{e} \cdot S_{o} \cdot Z_{o E}=0 \\
\text { ただし } K_{o}(m)=K_{o 0}(m) \cdot \exp \left(\frac{-E_{o}(m)}{R \cdot T_{w}}\right)
\end{gathered}
$$

$K_{o}(m)$ のパラメータは, 生物処理のときと同様にし て実測データから着目成分ごとに定まる.

一方，オゾンについては， $C_{o}(m)$ の濃度がそれ以外 の全ての被酸化物質に比べ低いので, 着目成分及びそれ 以外の全ての被酸化物質亡オゾンとの各反応速度の和に オゾンの自己分解を含めて総括的に取り扱い, アレニウ スの式を仮定して,

$$
J\left(T_{w}\right)=a_{0} \cdot \exp \left(\frac{-b_{0}}{T_{w}}\right)
$$

とおくと,オゾンに関する物質収支から次式が成立する.

$$
\begin{aligned}
G_{o} \cdot\left(Y^{i}-Y^{e}\right) & -L \cdot X^{e} \\
& =X^{e} \cdot S_{o} \cdot Z_{o E} \cdot J\left(T_{w}\right)
\end{aligned}
$$

式 (10)の $Y^{e}$ に式 $(7)$ を代入すると, 次式を得る.

$$
\begin{aligned}
G_{o} \cdot q \cdot\left[Y^{i}\right. & \left.-\left(X^{e} / \alpha_{o}\right)\right]-L \cdot X^{e} \\
& =X^{e} \cdot S_{o} \cdot Z_{o E} \cdot J\left(T_{w}\right)
\end{aligned}
$$

したがって, 式 (11) から $X^{e}$ が $Y^{i}$ に対応して決定 される.それを式（8）に適用すると, 式 ( 8 ) が着目 成分ごとの設計方程式となる. そのために, 式 (11) の $J\left(T_{w}\right)$ に含まれる $a_{0}, b_{0}$ を決定する必要がある. その 手順を示すと, まず, 式 (11) から式 (12) が得られる. 次に, 


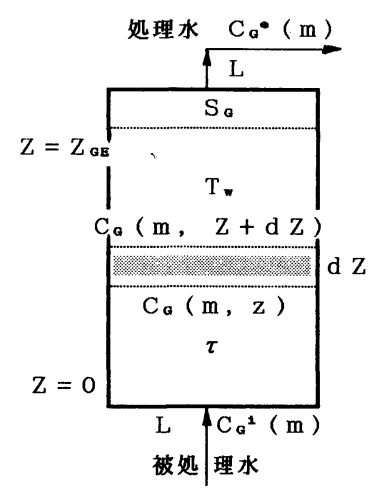

図一4 BAC 処理
表一1 設計方程式

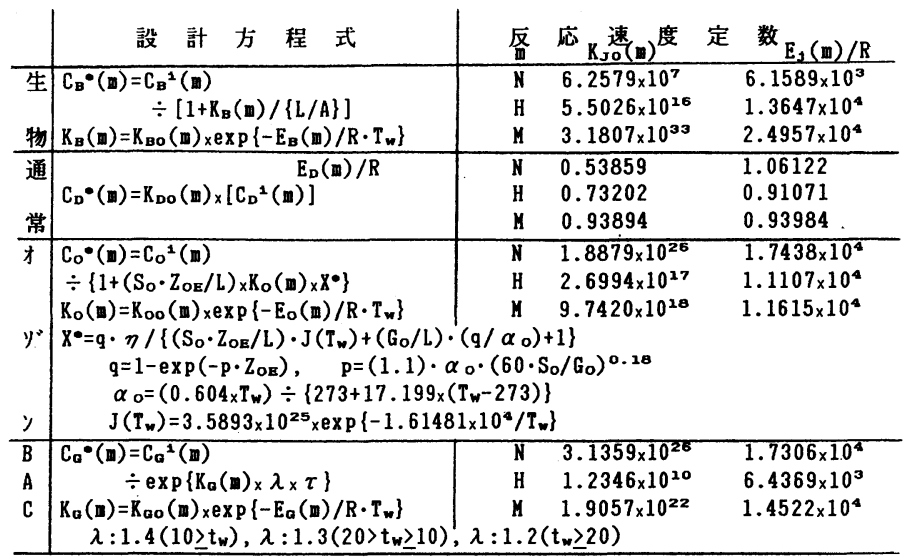

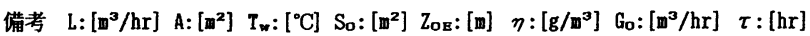

$$
\begin{array}{r}
X^{e}=q \cdot \eta \div\left[\left(S_{o} \cdot Z_{o E} / L\right) \cdot a_{0} \cdot \exp \left(\frac{-b_{0}}{T_{w}}\right)\right. \\
\left.+\left(G_{o} / L\right) \cdot\left(q / \alpha_{o}\right)+1\right]
\end{array}
$$

式（12）を変形して両辺の対数をとると, 次式を得る.

$$
\begin{array}{r}
\ln \left[\frac{\left\{\left(q \cdot \eta / X^{e}\right)-\left(G_{o} / L\right) \cdot\left(q / \alpha_{o}\right)-1\right\}}{\left(S_{o} \cdot Z_{o E} / L\right)}\right] \\
=\ln a_{0}-b_{0} / T_{w}
\end{array}
$$

ここに, オゾン注入率 $\eta=\left(G_{o} \cdot Y^{i}\right) / L$ であり, また, $q=1-\exp \left(-p \cdot Z_{o E}\right)$ の $p$ は, $K_{L} \cdot a$ に津野が既存文献の 整理から得た関係式 $K_{L} \cdot a=1.1\left(60 \cdot G_{o} / S_{o}\right)^{0.82}$ を用いる と $^{14)}, p=(1.1) \cdot \alpha_{o} \cdot\left(S_{o} / 60 \cdot G_{o}\right)^{0.18}$ である.

よって, 実測データのアレニウスプロットにより, 式 （13）の回帰式の切片之勾配から, $J\left(T_{w}\right)$ の定数 $a_{0}$ と $b_{0}$ が決定される.

以上のように, 式 (13) から $a_{0}, b_{0}$ が決定され, 式 (12) から $Y^{i}$ に応じ $X^{e}$ が求められると, その $X^{e}$ を用いて

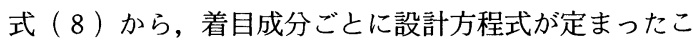
とになる.

\section{（4）粒状活性炭処理施設（BAC 施設）}

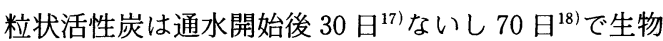
活性炭となり, 着目成分の除去は $B A C$ の吸着と微生物 の分解反応により定常状態19,201,21) で進行するので，本 報では，すでに生物活性炭の状態を形成しており，第 4 章 1 節(5で後述するとおり, 1 年間を 1 サイクルとする 定常状態の場合を取り扱う， $B A C$ 施設の処理方式は図 一4のように，デー夕を入手した実証プラントと同じで ある生物活性炭の流動層方式とする．食塩をトレーサと

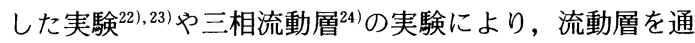
過する原水は栓流であることが確められている. $B A C$
の静止時の充填高さを $Z_{G E}$, 流動化による膨張率を入亡 すると，流動時の高さは $\lambda \cdot Z_{G E}$ に膨張する．流動層の 底面積を $S_{G}$ とすると, 空塔接触時間 $\tau$ は $S_{G} \cdot Z_{G E} / L$ で ある. 実測デー夕は活性炭が生物活性炭をすでに形成し ている期間であることから， $B A C$ 処理は生物分解処理 が卓越しているので,生物処理と同様に 1 次反応とする. 反応速度定数はアレニウスの式とし, 流動層の高さ $Z$ における微小体積 $S_{G} \cdot d Z$ について, 着目成分に関する 物質収支をとると次式が成立する。

$$
\begin{aligned}
& L \cdot C_{G}(m, Z)-L \cdot C_{G}(m, Z+d Z) \\
& =K_{G}(m) \cdot C_{G}(m, Z) \cdot S_{G} \cdot d Z \\
& \text { ただし, } K_{G}(m)=K_{G 0}(m) \cdot \exp \left(\frac{-E_{G}(m)}{R \cdot T_{w}}\right)
\end{aligned}
$$

これらを，底部及び頂部それぞれにおける次の境界条 件により解くと, 式 (15) を得る.

底部 $Z=0$ において, $C_{G}(m)=C_{G}{ }^{i}(m)$

頂部 $Z=\lambda \cdot Z_{G E}$ において, $C_{G}(m)=C_{G}{ }^{e}(m)$

$$
\begin{aligned}
\ln C_{G}{ }^{i}(m)-\ln C_{G}{ }^{e}(m) & =\frac{K_{G}(m) \cdot S_{G} \cdot \lambda \cdot Z_{G E}}{L} \\
& =K_{G}(m) \cdot \lambda \cdot \tau
\end{aligned}
$$

$\lambda$ の值は活性炭の種類や水温により異なるが，実証プ ラントでは季節ごとに $\lambda=1.4$ (冬期), $\lambda=1.3$ (春秋期), $\lambda=1.2$ (夏期）である. 反応速度定数のパラメータは, 生物処理のときと同様に, $C_{G}(m)$ ごとに実測デー夕を 式（15）に適用し，その切片と勾配加決定される.

以上の検討から得られた各施設の設計方程式は表一1 のよおりである.

なお，2-MIB のように他の 2 物質に比へ，生物分解 を受けにくい物質については，活性炭の状態（GAC ま たは $B A C)$ の捉え方によって，設計方程式が異なるこ 
とも予想されるが，上述の手続きによってモデル式を実 測デー夕と適合させることが出来たので, 最適設計のた めのものとしては, 生物処理を仮定したモデルで差し支 えないと考える。

\section{（5） 原水調整池及び浄水池の特性}

原水調整池の中の貯留水量は, 常に $Q_{1}$ であるとする.

\section{a) 原水調整池}

(1) 原水調整池の容量 $Q_{1}$ を利用し, 貯留水量 $Q_{1}$ と 変動する取水量 $L(t)$ とにより, 河川から取水後 の着目成分の濃度 $C_{Q 1}{ }^{i}(t)$ 之水温 $T_{w 0}(t)$ の時間 的な変動の平準化を図る。

(2) 原水調整池が完全混合亡すると, 着目成分の平淮 化は次式で規定されるが,最適化計算においては, 差分形に変形して計算する. 水温についても同様 である.

$$
\frac{d\left[C_{Q 1}{ }^{e}(m, t) \cdot Q_{1}\right]}{d t}=\left[C_{Q 1}{ }^{i}(m, t)-C_{Q 1}{ }^{e}(m, t)\right] \cdot L(t)
$$

b) 浄水池

(1) 通例の净水場に設けられている净水池の容量 $Q_{2}$ も水質を平準化し, 目標水質の達成に寄与する. 浄水池での平準化も完全混合とする.

(2) 水道統計から, $100 \times 10^{3} \mathrm{~m}^{3} / d$ クラスの用水供給 事業の净水池容量は 0.04 0.31 日分であるので, その容量を $Q_{2}=25 \times 10^{3} \mathrm{~m}^{3}$ とする.

\section{（6）費用関数式}

第 4 章 2 節 b ） で述べるとおり, 計算対象とする水質 安定システムの規模は, 最大送水量 $4500 \mathrm{~m}^{3} / \mathrm{hr}$ である. その規模について実施設計経験者からの聴取に基づき， 各処理施設の設計変数 $\{A, \eta, \tau\}$ の関数として, 建設 費式及び運転費式を回帰式により設定した結果を表一2 に示す.

なお，原水調整池の建設費は既報2 ${ }^{2}$ と同じである．净 水池は, 前節の b ）で容量一定としたので建設費も一定 である.よって，最適化計算上は便宜的に零とおく．

また，用地は手当済みとしたことから，建設費には含 めない,

建設費式と運転費式から年負担額の算出方法は既 報2),3) と同じであるが，その要点は以下のとおりである. 建設費は国庫補助金（補助率 $1 / 3$ ) の残額に起債 (5 年 据置, 30 年償還, 年利率 $7 \%$ ) を充当し, 減価償却（残 存価格 $10 \%, 30$ 年償還）の仮定を置く. 建設費は, 原 水調整池, 生物処理施設, 通常処理施設, オゾン処理施 設, 及び $B A C$ 施設をそれぞれ $E_{Q 1}, E_{B}, E_{D}, E_{o}$, 及 び $E_{G}$ として, 各施設の建設費の総和 $E$ を年間負担額 $\phi_{1}$ に換算して求める. また, 運転費は, 生物処理, 通 常処理, オン゙ン処理, 及び $B A C$ をそれぞれ $M_{B}, M_{D}$,
表一2 建設費 $\cdot$ 運転費関数式

\begin{tabular}{|c|c|}
\hline \multicolumn{2}{|c|}{ 建設費( $\times 10^{6}$ 円) } \\
\hline $\begin{array}{l}\text { 生 物 処 } \\
\text { 通理 } \\
\text { 常、処 } \\
\text { オ 理 } \\
\text { B A C 処 理 } \\
\text { 原 水調 整 池 } \\
\text { 浄水池(既設) }\end{array}$ & $\begin{array}{l}E_{B}=8.3243 \times 10^{-2} \times A^{0.7503} \\
E_{D}=1.5915 \times 10^{3}+1.1853 \times L_{0} \\
E_{O}=9.165 \times 10^{2}+2.8964 \times 10^{2} \times \eta \\
E_{G}=1.5862 \times 10^{3} \times \exp (1.9643 \times \tau) \\
E_{Q_{1}}=32.06 \times\left(Q_{1} / 1000\right)^{0.7711} \\
E_{Q_{2}}=0\end{array}$ \\
\hline 连䎳貝(1 & 円 $\left./ \mathbf{m}^{3}\right)$ \\
\hline $\begin{array}{llll}\text { 生 物 処 } & \text { 理 } \\
\text { 通 常 処 } & \text { 理 } \\
\text { オy “処 } & \text { 理 } \\
\text { B A C 処 } & \text { 理 } \\
\end{array}$ & $\begin{array}{l}M_{B}=8.359 \times 10^{-5} \times A^{0.7585} \\
M_{D}=18.469 \times L_{0}-0.1558 \\
M_{0}=0.515+0.6264 \times \eta \\
M_{Q}=0.9799 \times \exp (5.821 \times \tau)\end{array}$ \\
\hline
\end{tabular}

$M_{o}$, 及び $M_{G}$ として, これらの総和 $M に L(t)$ を乗じ た総額 $\phi_{2}$ である.これらを併せた年間総負担額 $\phi\left(=\phi_{1}\right.$ $\left.+\phi_{2}\right)$ を第 4 章 3 節で述べる最適化の計算手順により最 小化する.

費用関数式から年間負担額への算出の留意点は, 既 報 ${ }^{2}$ 之同様に以下のとおりである.

原水調整池及び各処理施設の建設費の総和 $E$ に対す る毎年の利息は $(2 \cdot E / 3) \cdot(1 / 15)$ であり，また，毎年 の減価償却は $(2 \cdot E / 3) \cdot(0.031)$ であるので, 両者の和 が毎年の負担額 $(2 \cdot E / 3) \cdot(0.1)$ となり, $E$ に対する毎 年の負担額 $\phi_{1}$ は, 次式で表わされる.

$$
\begin{gathered}
\phi_{1}=(2 / 3) \cdot\left[E_{Q 1}\left(Q_{1}\right)+E_{B}(A)+E_{D}\left(L_{0}\right)\right. \\
\left.+E_{o}(\eta)+E_{G}(\tau)\right] \cdot(0.1) \\
\text { ただし, } L_{0}=\max \{L(t)\}
\end{gathered}
$$

一方, 年間運転費 $\phi_{2}$ は, 表一 2 から単位水量当たり で規定されているので, 各処理水量（生物処理亡通常処 理は $10 \%$ 増）を乗じた総和の次式で与えられる.

$$
\begin{aligned}
\phi_{2}=\sum\left[( 1 . 1 ) \cdot \left\{M_{B}(A)\right.\right. & \left.+M_{D}\left(L_{0}\right)\right\} \\
& \left.+\left\{M_{o}(\eta)+M_{G}(\tau)\right\}\right] \cdot L(t)
\end{aligned}
$$

ここで, 各処理施設の設計変数と净化能力及び費用と の関係並びにこれらのトレードオフの関係について見る と，以下のとおりである.

各処理施設の净化能力, 費用のいずれもが, 表一 1 及 び表一2において設計変数の関数として表示されてい る. それによると, 净化能力の関数は, 三水質項目に対 し, 生物処理とオン゙ン処理が直線タイプ, $B A C$ が指数 タイプで表示され，それぞれ処理機能のレベルが異なっ ている. 費用の関数は, 生物処理がベき乗タイプ, オゾ ン処理が直線タイプ， $B A C$ が指数タイプで表示された。 それぞれ設計変数が大きくなると，三水質項目それぞれ の净化能力が向上するが，費用もまたそれぞれ増加する という意味において，トレードオフの関係にある. 三水 質項目の目標水質を達成し，総費用を最小化ならしめる 最適な設計変数を, 次章で述べる最適化計算により求め る. 


\section{4. 最適設計}

第 2 章で述べた水質安定システムモデルについて, 制 約条件である送水の三水質項目の目標水質 $C^{T}(m)$ を満 たした上で, 総費用 $\phi$ が最小となる最適システムを求 めるため, 以下の各節に述べるとおり, 計算の前提条件 を設定し, 計算対象の分類に従い, 前章で得られた設計 方程式及び費用関数式を用い, 本章第 3 節で述べる計算 手順により, 最適設計の計算プロセスを構成した。この 場合の設計変数と制約条件は, 次のとおりである. 設計変数：

(1) 原水調整池の容量 $Q_{1}$

(2) 第 3 章の冒頭で述べたとおり，処理施設ごとに

ハニカムチューブの表面積 $A$

オン゙ン注入率 $\eta$

$B A C$ の空塔接触時間 $\tau$

制約条件：

(1) 設計変数については, 次の 3 項目である. ハニカムチューブの面積が負にならないこと. $A \geqq 0$

オゾン濃度が負にならないこと. $\eta \geqq 0$

活性炭を流動化させるには, $\tau$ の值が一定以上の 断面流速が必要であること. また，断面流速が大 き過ぎて流動層の活性炭が流出しないこと.

$S_{G} \cdot Z_{G E} / \min \{\mathrm{L}(t)\} \geqq \tau \geqq S_{G} \cdot Z_{G E} / \max \{L(t)\}$

(2) 状態変数については, $m$ ごとに送水の水質 $C_{Q 2}{ }^{e}(m)$ が, それぞれの目標水質 $C^{T}(m)$ を越 えないこと.

$$
C^{T}(\mathrm{~m}) \geqq C_{Q 2}{ }^{e}(m)
$$

\section{（1）計算の前提条件}

(1) 河川の流況は取水制限が無いものとする.

(2) 導水から各施設を経由して送水されるまでは，自 然流下とする.

(5) 各処理施設における貯留は無いものとする.また, 反応は定常状態で等温反応とし，処理に伴う温度 変化は無いものとする.

(4) 通常処理から排出される洗浄排水などは, 着水井 に返送されるので, 生物処理施設と通常処理施設 における処理水量は $10 \%$ 増加するが，それによ る水質への影響はないものとする.

なお,返送ポンプの費用は考慮しないものとする.

(5) 計算のピッチ $\Delta t$ は半旬 (5 日間) 単位とし, 一 年間 $\left(73\right.$ 半旬) を 1 サイクル (初期 $: t_{I}$, 終期 : $\left.t_{E}\right)$ とする.

\section{（2）計算条件の構成とその分割}

水質安定システムの特性を把握するため, 原水と净水 の種々の条件下で最適化計算を行う必要があるが，その 条件は各条件ごとに水量と水質それぞれについて, 以下 のとおりである.

\section{a) 原水の条件}

(1) 水量：前節の(1)で述べたとおり, 取水制限が無い 河川流況亡する.

(2) 水質: 河川水質の年間変動パターンは, 淀川水系 下流の濃度が高い 1981 1993 年の場合を参考之 する. 各水質の季節変動は, 以下のとおりである. $\mathrm{NH}_{4}-\mathrm{N}$ は冬期に高く（最大 $: 2.31 \mathrm{~g} / \mathrm{m}^{3}$, 最小： $\left.0.07 \mathrm{~g} / \mathrm{m}^{3}\right), 2-\mathrm{MIB}$ は冬期に存在せず, 夏期に 高い（最大: $152 \times 10^{-3} \mathrm{~g} / \mathrm{m}^{3}$, 最小 $\left.: 0 \mathrm{~g} / \mathrm{m}^{3}\right)$, THM-FP の年間変動は前 2 者に比べ大きくない (最大： $138 \times 10^{-6} \mathrm{~g} / \mathrm{m}^{3}$, 最小 : $\left.30 \times 10^{-6} \mathrm{~g} / \mathrm{m}^{3}\right)$. 水温の変動は大きい $\left(\right.$ 最高 $: 30.4{ }^{\circ} \mathrm{C}$, 最低 $: 4.3$ $\left.{ }^{\circ} \mathrm{C}\right)$.

\section{b) 浄水の条件}

(1) 水量：最適化計算の対象とする水質安定システム の規模は日最大送水量 $100 \times 10^{3} \mathrm{~m}^{3} / d$ とする（数 個所の用水供給事業の例から, 日単位を時間単位 へ変換する係数の平均値は 1.08 であるので時間 最大送水量を $\max \{L(t)\}=4500 \mathrm{~m}^{3} / \mathrm{hr}$ とする).

送水量の年間変動パターン $L(t)$ は既報 ${ }^{2}$ の筑後 川水系から取水する用水供給事業の例による（最 大: $100 \times 10^{3} \mathrm{~m}^{3} / d$, 最小 $: 72 \times 10^{3} \mathrm{~m}^{3} / d$, 年間総 送水量: $\left.29.95 \times 10^{6} \mathrm{~m}^{3}\right)$.

(2) 水質: 着目成分 $\mathrm{m}$ ごとの目標水質の濃度は, 次 のとおりとする. $C^{T}(N)=0.3 \mathrm{~g} / \mathrm{m}^{3}$ (ジクロラ ミンなどによる異臭味の発生限界値. 以下, $\left\lceil\mathrm{g} / \mathrm{m}^{3}\right.$ 」を省略する. ) , $C^{T}(H)=30 \times 10^{-3} \mathrm{~g} / \mathrm{m}^{3}$ (水 質基準の健康項目. 以下, $\left\lceil\times 10^{-3} \mathrm{~g} / \mathrm{m}^{3}\right\rfloor$ を省略 する.), $C^{T}(M)=10 \times 10^{-6} \mathrm{~g} / \mathrm{m}^{3}$ (水質基準の快 適項目. さらに, 臭気閾値とされ, より厳しい值 である $5 \times 10^{-6} \mathrm{~g} / \mathrm{m}^{3}$ についても検討する. 以下, $\left\lceil\times 10^{-6} \mathrm{~g} / \mathrm{m}^{3}\right\rfloor$ を省略ずる. ).

目標水質のうち $C^{T}(M)$ については, 前述のとおり $C^{T}(M)=10$ と $C^{T}(M)=5$ の 2 ケースに分類する. ま た，原水調整池のみの場合とそれに浄水池の平準化効果 も考慮する場合の 2 ケースに分類する. したがって，原 水調整池の容量 $Q_{1}$ ごとに 4 ケースについて, 前述の第 3 章で示した設計方程式及び費用関数式を適用して費用 最小化の観点から最適化の計算を行う.

\section{（3）計算手順}

本章の第 2 節各項で述べた水量及び水質に関する入力 データを表一1の設計方程式に適用して, 図一 5 の計算 


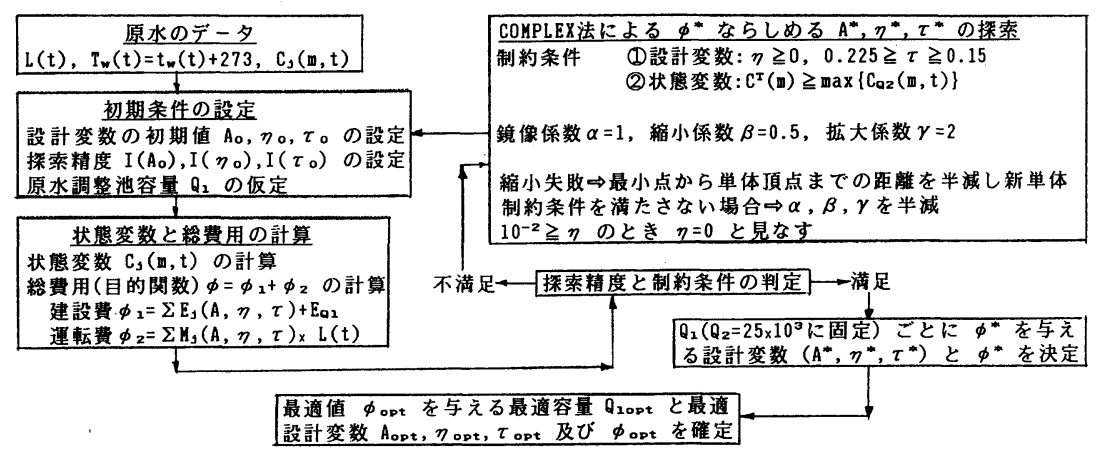

図一5計算手順フローチャート

手順フローチャートに従い, Boxのコンプレックス法

(Nelder \& Meadによる非線形最適化のためのシンプ レックス法の制約条件付き) $)^{25,26)}$ を用いる.

最適化計算の方法には，つぎの 2 方法がある.

(1) 目的関数の勾配を使用する方法.

(2) 勾配を求めることが困難な場合に目的関数の值だ けを用い，勾配を使用しない方法.

(2)の方法としては，コンプレックス法が制約条件つき の場合にも有効であるものとして知られている.

コンプレックス法では, 3 設計変数 $\{A, \eta, \tau\}$ に原 水調整池の容量 $Q_{1}$ を加えた 4 変数でも計算可能である が， $Q_{1}$ の值をあるピッチで変化させ，ある $Q_{1}$ の値に対 する $\{A, \eta, \tau\}$ だけの最適化問題として解く. その目 的は, 第 5 章で述べるとおり， $Q_{1}$ とその $Q_{1}$ の值に対す る総費用の最小値 $\phi^{*}$ 亡の間の興味深い挙動を観察する ために， $Q_{1}$ の值（計算のピッチを全体的な傾向を見る ためには $\Delta Q_{1}=5 \times 10^{3}$, 極值の近傍では $\Delta Q_{1}=1 \times 10^{3}$ $\mathrm{m}^{3}$ とする. ) ごとに $\phi^{*}$ の值とその時の設計值 $\left\{A^{*}, \eta^{*}\right.$, $\left.\tau^{*}\right\}$ を求めることにある. さらに、その結果から $Q_{1}$ の値 の変動に対する $\phi^{*}$ の最小値 $\phi_{\mathrm{opt}}=\min \left\{\phi^{*}\right\}$ となる $Q_{1 \mathrm{opt}}$ の值並びに最適設計值 $\left\{A_{\mathrm{opt}}, \eta_{\mathrm{opt}}, \tau_{\mathrm{opt}}\right\}$ を求めること ができる. コンプレックス法を適用する際に, 鏡像係数 $\alpha=1$, 縮小係数 $\beta=0.5$, 拡大係数 $\gamma=2$ とし, 縮小が不 成功の場合は最小点から単体までの距離を半減し新しい 単体を作る. また, 独立変数である設計変数と従属変数 である状態変数における制約条件は, 本章の冒頭で示し たが,これらを満足しない場合は， $\alpha, \beta, \gamma$ を半減し探 索を続ける.

なお, 計算過程において, つぎの点について留意する 必要がある.

(1) 原水調整池においては, 計算期間の初期値 $C_{Q 1}{ }^{e}\left(m, t_{1}\right)$ と最終值 $C_{Q 1}{ }^{e}\left(m, t_{E}\right)$ とが等しくなる ように, 着目成分ごとに試行錯誤により初期值を 設定する.

(2) 净水池において, 原水調整池と同様に試行錯誤に
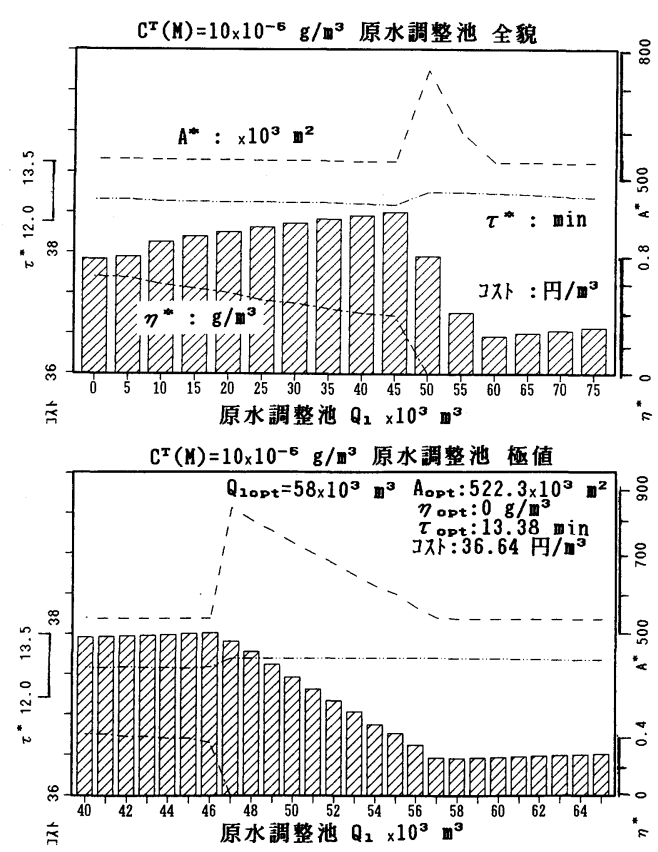

図一6 総費用 (コスト) の最小値とその設計変数の值 (原水調整池のみの場合 $C^{T}(M)=10 \times 10^{-6} \mathrm{~g} / \mathrm{m}^{3}$ ) 上段：全貌 $\left(0 \leqq Q_{1} \leqq 75 \times 10^{3} \mathrm{~m}^{3}\right)$

下段：極值近傍 $\left(40 \leqq Q_{1} \leqq 65 \times 10^{3} \mathrm{~m}^{3}\right)$

より, 初期値 $C_{Q 2}{ }^{e}\left(m, t_{I}\right)$ と最終値 $C_{Q 2}{ }^{e}\left(m, t_{E}\right)$ とが等しくなるように初期値を設定する.

\section{5. 最適設計とその挙動特性}

$C^{T}(M)=10$ のケースを例として， $Q_{1}$ の値ごとに求 めた $\phi^{*}$ の值とそれに対応する設計変数 $\left\{A^{*}, \eta^{*}, \tau^{*}\right\}$ の値との関係を，原水調整池のみの場合を図一6に，原 水調整池及び浄水池を有する場合を図一7に示した。 そ れぞれの上段には $Q_{1}$ の值に対する $\phi^{*}$ の値と $\left\{A^{*}, \eta^{*}\right.$, $\left.\tau^{*}\right\}$ の値についての全体的な傾向を, 下段には極値の近 

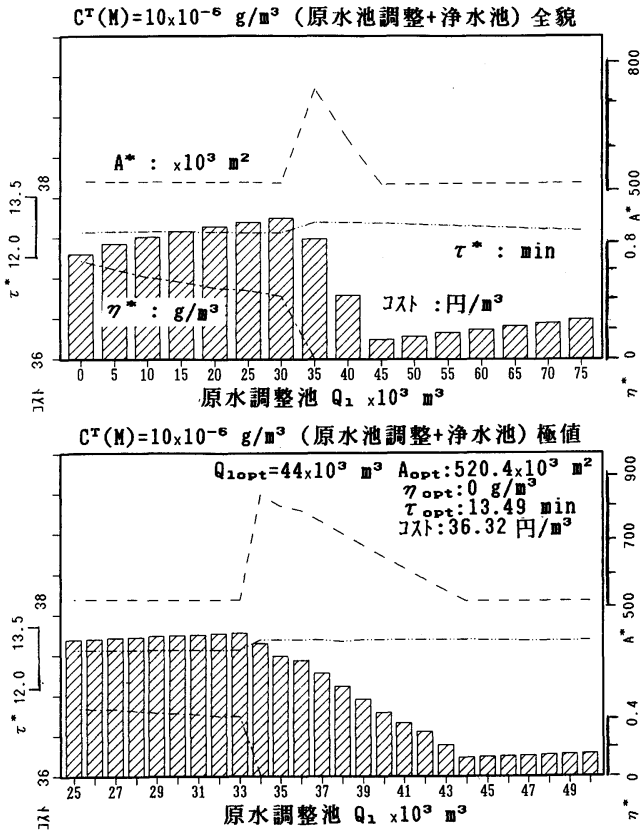

図一7 総費用 (コスト) の最小値とその設計変数の值 (原水調整池十净水池 $C^{T}(M)=10 \times 10^{-6} \mathrm{~g} / \mathrm{m}^{3}$ ) 上段 : 全貌 $\left(0 \leqq Q_{1} \leqq 75 \times 10^{3} \mathrm{~m}^{3}\right)$

下段：極值近傍 $\left(25 \leqq Q_{1} \leqq 50 \times 10^{3} \mathrm{~m}^{3}\right)$

傍におけるそれぞれの値の挙動を示す.これらから, 設 計変数, 総費用, 及び送水水質について, それぞれ以下 のことが分かる.

\section{（1）原水調整池のみの場合}

\section{a) 設計変数}

図一6によると, $Q_{1}$ の値の増大に伴い設計変数の值 は減少傾向にあるが, $Q_{1}=46 \times 10^{3} \mathrm{~m}^{3}$ (以下, $\left\lceil\times 10^{3} \mathrm{~m}^{3}\right.$ 」

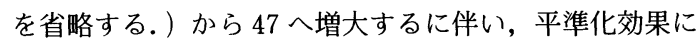
よりオン゙ン処理が不要 $\left(\eta^{*}=0\right)$ となる. 一方, $A^{*}$ の 值はオゾン処理が不要となった機能を補完するために, 断層的に急上昇し， $\tau^{*}$ の值も $10 \%$ 増大する. さらに, $Q_{1}$ の値の増大に伴い $\eta^{*}=0$ の継続状態で, $A^{*}$ 亡 $\tau^{*}$ の 值は, 減少しつつ $\eta^{*}=0$ となる前の状態へ近づく.

\section{b）総費用}

$Q_{1}$ の值の増大に伴い $\phi^{*}$ の值は増大するが, $Q_{1}=50$ の近傍でオゾン処理を不要とするため, $\phi^{*}$ の值は急減 する. さらに, $Q_{1}$ の値の増大に伴い漸次 $A^{*}$ と $\tau^{*}$ それ ぞれの値の減少により $\phi^{*}$ の值も減少するが, $Q_{1}=59$ で 増加に転ずるので, $\phi^{*}$ の值は $Q_{1}=58$ のとき, $\phi_{\mathrm{opt}}=$ $\min \left\{\phi^{*}\right\}$ となる. その際, 設計変数 $A^{*}=522.3 \times 10^{3} \mathrm{~m}^{2}$

(以下, $\left\lceil\times 10^{3} \mathrm{~m}^{2}\right\rfloor$ を省略する.) $, \eta^{*}=0, \tau^{*}=0.2246$ $\mathrm{hr}(=13.38 \mathrm{~min}$. 以下, $\min$ 単位のみとし, 「 $\mathrm{min} 」 を$ 省略する.）において, 最適値 $\phi_{\mathrm{opt}}=1097.22 \times 10^{6}$
円 $/ y r\left(\right.$ 単位水量当たりに換算したコスト 36.64 円 $/ \mathrm{m}^{3}$. 以下 $\left\lceil\times 10^{6} \mathrm{~m} / \mathrm{yr} 」\right.$ と 円 $\left./ \mathrm{m}^{3}\right\rfloor$ を省略する.）となる. これは原水調整池が存在しない場合 $\left(Q_{1}=0\right)$ に比べ約 $5.6 \%$ 安い. この場合, オン゙ン処理が不要 $\left(\eta^{*}=0\right)$ で あるので, 前項のとおり $A^{*}$ の值を増大するほか, $\tau^{*}$ の值も長くする必要があるが, $\tau^{*}$ の值は平準化効果に より $Q_{1}=0$ の場合のそれよりも $6.5 \%$ の延長にすぎな い.

\section{c）送水水質}

ある $Q_{1}$ の值に対して総費用が最小となる $\phi^{*}$ の場合, それに対応する送水の水質 $C_{Q 2}{ }^{e}(N, t), C_{Q 2}{ }^{e}(H, t)$, 及び $C_{Q 2}{ }^{e}(M, t)$ の最高濃度の挙動は, 目標水質との対 比において, 次のとおりである.

$C_{Q 2}{ }^{e}(N, t)$ の最高值は $Q_{1}$ の値の変化に拘らず, 目標 水質よりもやや小さく, ほぼ 0.3 に等しい. しかし; $\eta^{*}=0$ となる $Q_{1}=47$ では, $A^{*}, \tau^{*}$ の值が急増すること により, 他の $Q_{1}$ の値の場合に比べ大略 $40 \%$ 濃度が低 い. $C_{Q 2}{ }^{e}(H, t)$ の最高値は, 目標水質より大略 $15 \%$ 小 さく, $\eta^{*}=0$ となる場合を除きほとんど変動しない. $C_{Q 2}{ }^{e}(M, t)$ の最高値は $Q_{1}$ の值の変化に拘らず常に目標 水質に等しい. つまり, $C_{Q 2}{ }^{e}(M, t)$ の值が，ある $Q_{1}$ の 值に対する費用を最小ならしめる設計変数の值を, 支配 していることになる.

\section{（2）原水調整池及び浄水池を有する場合}

図一6に示した前節の場合（以下，「前者」という.) と図一7に示す本節の場合 (以下,「後者」という.) と の主な相違点は, 以下のとおりである.

\section{a) 設計変数}

ある $Q_{1}$ の值での総費用の最小値 $\phi^{*}$ とそのときの設 計変数の值 $\left\{A^{*}, \eta^{*}, \tau^{*}\right\}$ を $Q_{1}$ の值ごとに前者と後者 とで比べると，オゾン処理を不要 $\left(\eta^{*}=0\right)$ とするに至 る $Q_{1}$ の值は, 後者が前者よりも 13 小さい $Q_{1}=34$ であ る. また, この場合の $Q_{1}$ の值は前者のそれよりも小さ いので, 後者は $2 \%$ 大きい $A^{*}$ の值を必要とするが $\tau^{*}$ の値は両者ともほぼ同じである.

\section{b) 総費用}

後者における総費用の最適値は $\phi_{\mathrm{opt}}=1087.67$ (コス ト $=36.32)$ であり, その場合の条件は $Q_{1}=44$ のとき で $A_{\mathrm{opt}}=520.4, \eta_{\mathrm{opt}}=0$, 及び $\tau_{\mathrm{opt}}=13.49$ である.こ れに対して, 前者では $Q_{1}=58$ において， $\phi_{\mathrm{opt}}=1097.22$, $A_{\mathrm{opt}}=522.3, \eta_{\mathrm{opt}}=0$, 及び $\tau_{\mathrm{opt}}=13.38$ であるので, 後 者は前者に対し $\phi_{\mathrm{opt}}, Q_{1}$, 及び $A$ のいずれの値におい ても大略 $10 \times 10^{6} \mathrm{~m} / \mathrm{yr}(=0.9 \%), 14 \times 10^{3} \mathrm{~m}^{3}(=24 \%)$ ， $1.9 \times 10^{3} \mathrm{~m}^{2}(=0.4 \%)$ 小さい.

なお, 後者で総費用の最適値の場合における費用構成 割合を示す図一8から，その割合は建設費が約 $70 \%$, 運 転費が約 $30 \%$ である. 建設・運転費ともに通常処理が 
掏用 $1087.67 \times 10^{6}$ 円 $/ \mathrm{yr}\left(=36.32 \mathrm{~W} / \mathrm{m}^{3}\right)$

建設車

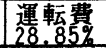

建設費 $773.72 \times 10^{6}$ 円 $/ y r$

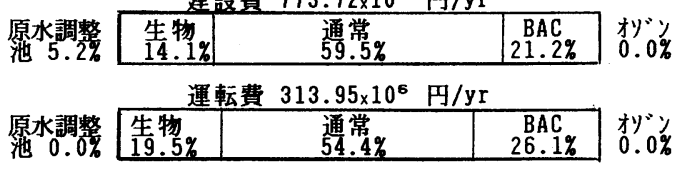

図一8＼cjkstart最適設計における費用の構成
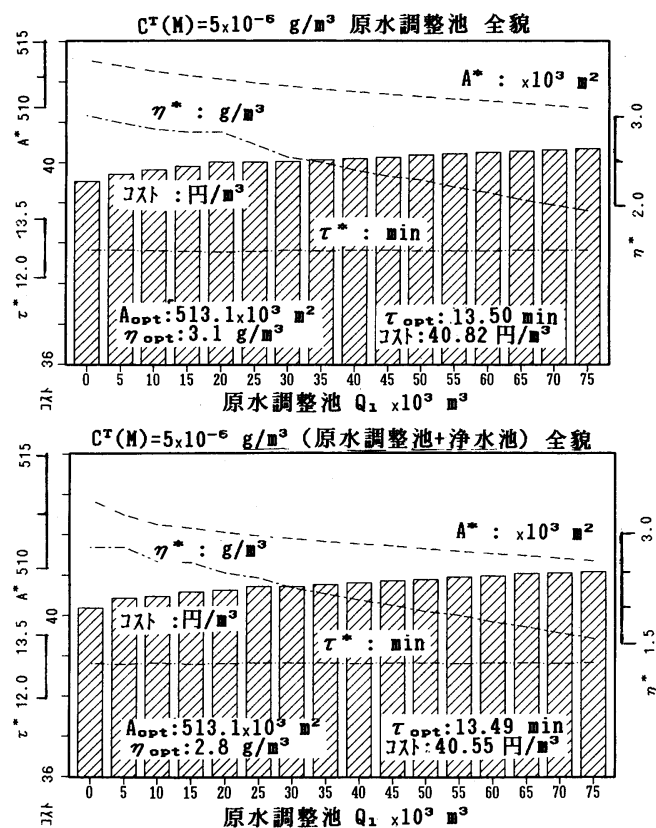

図一9 総費用 (コスト) の最小値とその設計変数の值 上段：(原水調整池のみ $C^{T}(M)=5 \times 10^{-6} \mathrm{~g} / \mathrm{m}^{3}$ )

下段：(原水調整池十净水池 $C^{T}(M)=5 \times 10^{-6} \mathrm{~g} / \mathrm{m}^{3}$ )

その半分を占め, 残りが高度処理である.

\section{c) 送水水質}

$\phi_{\mathrm{opt}}$ において, 後者の $C_{Q^{2}}{ }^{e}(N, t)$ の最高値は, 前者 のそれに比べさらに約 $10 \%$ 小さい. $C_{Q 2}{ }^{e}(H, t)$ の最高 值は $Q_{1}$ の值に拘らず約 $0.5 \%$ ほど前者よりも高い傾向 にあるが,制約条件である目標水質を越えることはない， 一方, $C_{Q 2}{ }^{e}(M, t)$ の最高值は, 両者とも制約条件であ る目標水質に等しい，このことからも, 前節 c ) で述へ たことと同様に $C_{Q 2}{ }^{e}(M, t)$ の值が, 最適設計変数の值 を支配していることになる。

\section{（３） 2-MIBの目標水質を厳しくした場合}

前節 c ) で記述したとおり, $C_{Q 2}{ }^{e}(M, t)$ の值が最適 設計変数の值を支配しているので, 制約条件がより厳し い $C^{T}(M)=5$ についても計算した。 その結果を原水調
整池のみの場合を図一 9 の上段に，原水調整池及び浄水 池を有する場合を同図の下段に示す．これから以下のこ とがわかる。

オゾン処理を不要 $\left(\eta^{*}=0\right)$ とする $Q_{1}$ の值は存在し ないが， $\phi^{*}$ の值は $Q_{1}$ の値に対し単調増加である。この ため, $\phi_{\mathrm{opt}}$ は $Q_{1}=0$ で達成される. $\phi_{\mathrm{opt}}$ の值は, $C^{T}(M)$ $=10$ の場合に比へ，原水調整池のみの場合, 浄水池も 有する場合それぞれにおいて，約 10\%，約 20\% 大きい. 設計変数は $C^{T}(M)=10$ の場合に比べ, $\eta^{*}$ の值はかな

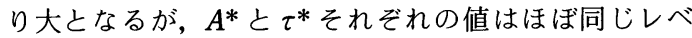
ルであるので，オゾンが 2-MIB の低減に有効であるこ とを裏づけている.

\section{6. 考 察}

総費用などへの原水調整池などによる平準化の効果， 設計変数の挙動の関係，送水水質などの観点から水質安 定システムの特性について，原水調整池及び浄水池を有 する場合を対象に，制約条件が $C^{T}(M)=10$ を基本に 記述する.

\section{（1）平準化の有無による設計変数などの比較}

総費用の最小値，その時の設計変数の値について平準 化の有無により，次の 3 ケースに分けて比較した．比較 のレベルを揃えるため，本報がこれまで取上げている原 問題と異なる次の仮定をおく. 即ち, 原水調整池の容量 を净水池のそれに等しい $Q_{1}=Q_{2}=25$ とする. さらに, 前章までは第 3 章 6 節で述べた理由から，原水調整池の みその建設費を算入していたが，その費用は次のケース (3)において除く.

ケース (1)：原水調整池と浄水池のいずれも存在しない とした場合.

ケース(2)：浄水池が有り，原水調整池が無しとした場 合.

ケース(3)：原水調整池が有り，净水池が無しとした場 合.

\section{a) 設計変数}

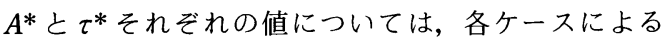
その差はほとんどないが, $\eta^{*}$ の值はケース(2)に比べケ一 ス(3)が著しく小である. 即ち, 原水調整池が浄水池より も平準化の効果が高い.

\section{b）総費用}

安価な順にケース(3)，ケース(2)，ケース(1) となり， 原水調整池による平準化の費用効果（設計変数に対応し た建設費並びに運転費も含め) が明らかである.

\section{（2）オゾン処理が不要となる場合の設計変数の挙動}

図一7 の場合, $Q_{1}=34$ でオゾン处理が, 不要 $\left(\eta^{*}=0\right)$ 
となる. それに対応する ${ }^{*}$ の值は, オゾン処理機能を 補完するため, 上限值 13.5 の近くまで長くなる. した

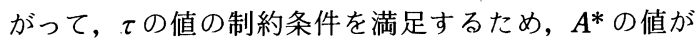
大きくなることによりオゾン処理機能が補完される.

\section{（3）オゾン処理を不要とするときより大なる $\boldsymbol{Q}_{1}$ の值 で最適値となる理由}

図一7において，ある $Q_{1}$ の值 $\left(Q_{1}=34\right)$ でオゾン処 理が不要 $\left(\eta^{*}=0\right)$ となっても, さらに大きい $Q_{1}$ の値 $\left(Q_{1}\right.$ =44）に至るまで $\phi^{*}$ の值が $\phi_{\mathrm{opt}}$ とはならない. その理 由は, 以下のとおりである.

$Q_{1}$ の値の増大に伴う平準化効果の増大により, $A^{*}$ の 值は, 急増前のレベルに逐次戻る.このため, $\tau^{*}$ の值 は制約条件である目標水質を達成するために $Q_{1} \leqq 44$ ま で, その上限值 13.5 に張り付いたままである. 一方, $Q_{1}$ の值の増大に伴う $A^{*}$ の値の減少による生物処理施 設の建設費の減少分 $d E_{B} / d Q_{1}$ は， $Q_{1}$ の建設費の増大分 $d E_{Q 1} / d Q_{1}$ の 6.5 倍である. このため, $Q_{1}$ の值の増大に 伴い, 生物処理の建設費が減少することと相まって運転 費も減少するので, オゾン処理を不要 $\left(\eta^{*}=0\right)$ とする $Q_{1}=34$ において, 総費用は最適值とならずに, $Q_{1}=44$ において最適値となるまで $\phi^{*}$ の值は減少を続ける.

\section{7. おわりに}

水道水からの異臭味の発生, 農薬やトリハロメタンな ビの検出により，水道水質に対する不信や不安が国民の 間に広まっている. 抜本的な対策は, 水道水源の水質保 全であるが，その達成には関係者の協力が不可欠である ことから，なお時間を要するものと憂慮される.このた め, 水道事業者の間では良質な浄水を供給する方策の一 つとして, 浄水処理に要するコストが増大するものの, 高度処理を導入する動きが活発化してきている1).

このような背景から, 高度処理を含む浄水処理システ ムに原水調整池と浄水池を組合せた水質安定システムを 設定した. 当該システムにおいて, 制約条件である目標 水質を達成し，かつコストを最小ならしめる最適設計問 題を採り上げた. そのシステムモデルとして異臭味や安 全性と関連が深いトリハロメタンなど三水質項目を対象 に, 水質安定システムを構成する施設ごとに, 原水水温 の季節変動による影響をアレニウスの反応速度定数で反 映しながら，実証プラントから得られたデータを用い， 物質収支と速度式に基づく物理的な現象モデルに基づき 設計方程式を定式化し，併せて，コスト最小化の最適問 題を設定するために，費用関数式を定式化した.

このシステムモデルを淀川下流の河川水質に適用し て,この問題の現実性と妥当性を検証した. 即ち, コン プレックス法により制約条件である目標水質を達成し,
且つ総費用を最小ならしめる最適設計の計算が可能であ り, その解が現実に求められ，それが常識的な值である と考えられる. さらに，原水調整池や浄水池の平準化効 果を考慮することにより 2-MIB の濃度制約条件が比較 的ゆるい場合には, 原水調整池がある程度大きくなると, オゾン処理を不要とするシステム特性を有することも判 明した。

また, 本報のシステムモデルの定式化と最適設計問題 の設定, 及びその数值解法は, 着目成分の設計方程式を 同定するならば，4成分以上の多成分系にも拡張可能な 方法論を与えているものである. 本報では河川取水量に 制限がない場合を取り扱ったが，この方法は渇水などに より取水制限が実施された場合にも，目標水質と送水量 の両方を確保するため, 即ち, 原水調整池などの流量調 整機能を活用することにより，目標とする水量と水質の 両方に制約条件がある場合にも，拡張が可能である.

本報で述べた方法論を活用することにより，例えば， 以下のことが可能である.

(1) 目標水質のレベルや原水調整池の容量と最小コス トとの関係を定量的に把握すること.

(2) それに基づき, 高度処理を含む水質安定システム の導入に当たり, 需要家の積極的なコンセンサス を得て, 当該事業を推進するために説得力のある 論理的なメニューを提示すること.

なお, 着目成分は, 例えば, 化学工業においては主成 分であり, その濃度は一般的に高い. 一方, 水道の净水 処理においてはその逆であり, 通例その濃度は極めて低 い.このため, 着目成分のデータの精度を上げ, 設計方 程式における反応速度定数のパラメータの精度を確保す ることによる最適化計算全体の精度向上を図る観点か ら，多くの実験データを集積したデータベースを構築す ることが，今後に残された課題であろう.

謝辞：貴重なデータをご提供下さった大阪府，大阪市， 及び阪神水道企業団をはじめ多くの水道事業の方々, ま た，種々アドバイスを下さった方々や相談に応じていた だいた方々に厚くお礼を申上げます.

\section{参考文献}

1）例えば, 早貸外幸, 粕谷明博, 真柄泰基：水道における 高度净水処理の現況亡課題, 京都大学環境衛生工学研究 会第 13 回シンポジウム講演論文集, Vol. 5, No. 3, pp. 213-218, 1991.

2）早貸外幸, 真柄泰基, 乙間末広 : 水量及び水質の安定供 給システムにおけるコスト最小化に関する一考察, 水道 協会雑誌, No. 12, pp. 3-11, 1990.

3）早貸外幸, 真柄泰基, 大井紘, 乙間末広 : 渴水時を含む 水道の安定供給システムの特性に関するコスト分析, 土 木学会論文集, No. 491/II-27, pp. 89-98, 1994. 
4) 森田徳義: 反応工学要論, 3. 連続流摚汼槽形反応器, pp. 20-30, 槙書店, 1987.

5) 橋本健治: 反応工学, 5 . 反応装置の設計と操作, pp. 81-86, 培風館, 1991 .

6）化学工学協会編：化学工学便覧 (改訂 5 版), 3. 化学反 応速度, p. 185, 丸善, 1988.5.

7）浜野守, 佐藤壮夫, 藤好紘一郎, 河相則夫 : 大阪府にお ける生物処理実験, 水道協会雑誌, Vol. 54, No. 9, pp. 12-31, 1985.

8）平田彰, 保坂幸尚：生物膜法における好気性生物処理特 性の評価, 水質污濁研究, Vol.12, No.6, pp. 373-379, 1989.

9）諸岡成治, 池水喜義, 加藤康夫 : 水溶液中のオゾンの自 己分解, 化学工学論文集, Vol. 4, No. 4, pp. 377-380, 1978.

10）津野洋 (宗宮功編)：オゾン利用水処理技術，公害対策技 術同友会, pp. 123-155, 1989.

11）森岡崇行, 本山信行, 星川寛, 岡田光正, 茂庭竹生 : 横 流接触池のオゾン吸収モデル, 水道協会雑誌, Vol.60, No. 7, pp.7-17, 1991.

12）森岡崇行, 本山信行, 星川寛, 岡田光正, 茂庭竹生 : 横 流式オゾン接触池の滞留時間分布特性, 水道協会雑誌, Vol.60, No.2, pp.11-21, 1991.

13）中道裕治, 皆川欽一, 青木優和, 浦野紘平 : (4-21) 相模 川下流水のオゾン処理, 第 42 回全国水道研究発表会講演 集, pp. 154-156, 1991.

14）津野洋：オゾン処理とオゾンの水への吸収特性, 水質污 濁研究, Vol. 13, No.12, pp. 786-791, 1990.

15）田畑則一：上水のオゾン処理における気液接触装置の特 性, 水道協会雑誌, Vol.43, No.11, pp. 16-27, 1974.

16）宗宮功, 津野洋, 田中稔, 山口直喜：オゾン処理による
かび臭物質の除去特性に関する研究, 水道協会雑誌, Vol. 57, No. 7, pp. 2-9, 1998.

17）浦野紘平, 渡辺茂樹, 岩瀬葉子, 藤江幸一：有機ハロゲ ン前駆物質の分子量之粒状活性炭の固定床吸着性能，水 質污濁研究, Vol.14, No.7, pp.451-459, 1991.

18）黒沢義乗, 真柄泰基, 武藤暢夫：生物活性炭による有機 性污染物質の除去, 水質污濁研究, Vol.11, No. 9, pp. 590-598, 1988.

19）渡辺茂樹, 皆川欽一, 久澤賢一郎, 浦野紘平 : (4-25) 相 模川下流水の生物活性炭処理の基礎特性, 第 42 回全国水 道研究発表会講演集, pp. 166-168, 1991.

20）堀内功一, 松永直利：(3-28) オゾン処理における $B A C$ 用活性炭の寿命予測, 第 39 回全国水道研究発表会講演集, pp. 179-181, 1988.

21）武蔵昌弘, 黒沢義乗, 真柄泰基：(4-35) 生物活性炭に関 する研究 · II ), 第 38 回全国水道研究発表会講演集, pp. 204-206, 1987.

22）千葉県水道局水質問題研究会 : 原水污濁等を原因とする 水質問題の処理に関する研究報告書, pp. 236-261, 1974 年 3 月.

23）熱田誠一, 森幸夫：石油系球状微粒炭による流動床処理 実験, 水道協会雑誌, No. 489, pp. 39-60, 1975.

24）平田彰, 保坂幸尚, 海宝益典, 大西秀典 : 三相流動層に よるフエノール廃水処理の生物処理特性, 水質污濁研究, Vol.11, No.9, pp. 561-568, 1988.

25) M.J.Box et al : Non-linear Optimization Techniques, Nomograph No.5, I. C. I, pp.20-24, 52-54, 1969.

26）化学工学協会編：BASIC による化学工学プログラミン グ, 培風館, pp. 88-92, 129-134, 261-262, 1985.

(1995.3.14 受付)

\title{
AN OPTIMAL DESIGN OF A HIGHLY UPGRADED WATER SUPPLY SYSTEM ON PHISICAL PHENOMENA MODEL OF MULTI WATER QUALITY ITEMS
}

\author{
Sotoyuki HAYAKASHI, Yasumoto MAGARA, Ko OI and Iori HASHIMOTO
}

An optimal design procedure of a water supply system with a raw water reservoir and a clean water basin as well as advanced treatment facilities of an ozonization process and a BAC is proposed. This procedure deals with the requirement of three water quality parameters, i.e. $\mathrm{NH}_{4}-\mathrm{N}$, THM-FP, and 2-MIB. To minimize the sum of the construction cost and the operation cost of the system, a formulation and a way to solve the optimization problem are given. A design equation with a reaction constant of the Arrhenius' equation is obtained through a model based on physical phenomena taking into account the data derived from a test plant study. An approprietness of this optimal design procedure is verified through its application to an actual case using the Complex Method of an optimization technique. 